Western University

Scholarship@Western

Aboriginal Policy Research Consortium International (APRCi)

2000

\title{
Violent Victimization and Fear of Crime Among Canadian Aboriginals
}

Michael Weinrath

Follow this and additional works at: https://ir.lib.uwo.ca/aprci

Part of the Criminology Commons

Citation of this paper:

Weinrath, Michael, "Violent Victimization and Fear of Crime Among Canadian Aboriginals" (2000). Aboriginal Policy Research Consortium International (APRCi). 259.

https://ir.lib.uwo.ca/aprci/259 
This article was downloaded by: [University of Western Ontario]

On: 25 October 2012, At: 13: 19

Publisher: Routledge

Informa Ltd Registered in England and Wales Registered Number: 1072954

Registered office: Mortimer House, 37-41 Mortimer Street, London W1T 3J H, UK

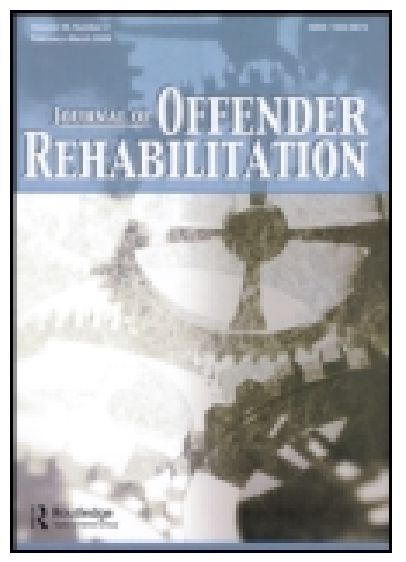

\section{J ournal of Offender Rehabilitation}

Publication details, including instructions for authors and subscription information:

http:// www.tandfonline.com/loi/ wjor20

\section{Violent Victimization and Fear of Crime Among Canadian Aboriginals}

Michael Weinrath PhD ${ }^{\text {a }}$

a Department of Sociology, University of Winnipeg, Winnipeg

Version of record first published: 12 Oct 2008.

To cite this article: Michael Weinrath PhD (2000): Violent Victimization and Fear of Crime Among Canadian Aboriginals, J ournal of Offender Rehabilitation, 30:1-2, $107-120$

To link to this article: http:// dx.doi.org/ 10.1300/ J 076v30n01_07

\section{PLEASE SCROLL DOWN FOR ARTICLE}

Full terms and conditions of use: http://www.tandfonline.com/page/termsand-conditions

This article may be used for research, teaching, and private study purposes. Any substantial or systematic reproduction, redistribution, reselling, loan, sub-licensing, systematic supply, or distribution in any form to anyone is expressly forbidden.

The publisher does not give any warranty express or implied or make any representation that the contents will be complete or accurate or up to date. The accuracy of any instructions, formulae, and drug doses should be independently verified with primary sources. The publisher shall not be liable for any loss, actions, claims, proceedings, demand, or costs or damages 
whatsoever or howsoever caused arising directly or indirectly in connection with or arising out of the use of this material. 
Race, Ethnicity, Sexual Orientation, Violent Crime: The Realities and the Myths. Pp. 107-120.

E 2000 by The Haworth Press, Inc. All rights reserved.

\title{
Violent Victimization and Fear of Crime Among Canadian Aboriginals
}

\author{
MICHAEL WEINRATH \\ University of Winnipeg
}

\begin{abstract}
Violent victimization by offenders has led to concerns over the negative consequences that this has on victims, including a greater fear of crime. Because their disadvantaged status leads to greater rates of violent victimization, it is speculated that fear of crime will be higher among the poor and racial minorities. Examining the common violent crime of assault, this hypothesis is tested by comparing the results of two national Canadian surveys, the 1991 post-censal Aboriginal People's Survey $(\mathrm{N}=18,000+)$, and the 1993 Canadian General Social Survey $(\mathrm{N}=10,000+)$. Contingency tables (cross-tabs) and multivariate logistic regression are used to assess differences in reported fear levels between Aboriginal and Non-Aboriginal cases. While Aboriginal rates of violent victimization are higher, there are no appreciable differences in fear levels. In some situations Non-Aboriginal Canadians are even more likely to report fear. This relationship holds even in controlled analysis for urban based Aboriginals and Non-Aboriginals. Assault does not substantially increase the fear levels of either group. Income differences between Aboriginals and Non-Aboriginals are a concern. Low income earners are more afraid, while high income earners are not. While other factors mediated some of these effects, policy makers need to direct attention to the large number of urban based, impoverished Aboriginals. [Article copies available for a fee from The Haworth Document Delivery Service: 1-800-342-9678. E-mail address: getinfo@haworthpressinc.com <Website: http:// www.haworthpressinc.com>]
\end{abstract}

KEYWORDS Canada's First Nations people, phenomenology of fear, poverty and crime, effects of assault 


\section{INTRODUCTION}

In the last decade, investigators have given more attention to the relationship between race and victimization, particularly for violent crimes. Academics have commented on the higher violent victimization rates experienced by disadvantaged groups such as Native Americans and Canadian Aboriginals (Bachman, 1992; Roberts \& Doob, 1997; Long, 1996; Weinrath, 1998). For many racial minorities, a greater chance of becoming a crime victim is added to the day to day stresses associated with low income and discrimination.

This paper examines the relationships between fear of crime, victimization and race. Analysis is driven by two general research questions which will hopefully lead to an increase in our limited knowledge regarding fear of crime and Canada's Aboriginal peoples. First, what are the correlates of Aboriginal fear of crime, and are they similar to those reported for NonAboriginals? Second, are there differences in fear levels between Aboriginals and Non-Aboriginal Canadians?

\section{REVIEW OF THE LITERATURE}

\section{Race and Fear of Crime}

Fear of crime "vulnerability" models are concerned with the higher fear levels among groups in society that perceive themselves as more likely to be victimized. This fear may be due to perceptions of an inability to defend one's self, as might be found among those who are female, elderly, or poor (Box, Hale \& Andrews, 1987; Ollenburger, 1981). Feelings of vulnerability may also be related to a lack of social support, or trauma resulting from victimization (Garafolo, 1979; Weinrath \& Gartrell, 1996). Urban residence, with greater perceived crime, is also thought likely to increase fear (Keane, 1992).

Race may also affect feelings of vulnerability and fear of crime, because the reality of minority status is having limited resources and living in high crime areas (Ortega \& Myles, 1987). While some studies involving AfricanAmericans have shown that they are more afraid than whites (Parker \& Ray, 1990; Skogan \& Maxfield, 1981), others have not. Ortega and Myles (1987) found that young Black males, despite a higher probability of victimization, were less afraid than Whites of the same age. They speculated that this may be due to subcultural norms that heavily emphasize street toughness for young Blacks. Conversely, they found that older Black males were more afraid than older White males. They attributed this to a greater likelihood of older Blacks residing in high crime neighborhoods, resulting in greater per- 
ceived vulnerability to young perpetrators, compounded by the problem of having less income (than Whites) to arrange protection.

LaPrairie's 1994 survey of inner city residents in Canada represents one of the few Aboriginal fear of crime studies. She surveyed 603 inner city Natives in several cities, finding that 16 percent of her subjects were afraid of being victimized, 30 percent were somewhat afraid, and 55 percent reported that they were not afraid. The wording of her measure is, unfortunately, not directly comparable to the more common fear indicator used in Canadian surveys and international surveys (van Vijk \& Mayhew, 1997), "Are you afraid to walk alone in your neighborhood at night?" Thus while 73 percent of Canadians felt "safe" in a recent national survey when asked this question, it is not fair to contrast this result with the 55 percent "safe" figure reported in LaPrairie's study, because her question asks about perceived safety from general victimization, not fear of walking in one's neighborhood. Furthermore, LaPrairie's Aboriginal sample is very select. Many Aboriginals live in rural settings, while many who live in cities do not experience the hardships faced by inner city populations. To clarify possible differences in fear of crime perceptions between Aboriginal and Non-Aboriginal Canadians, comparison of more representative samples is needed.

\section{Violent Victimization}

Official records and self-report surveys show greater violent victimization rates for Canadian Aboriginals. Compared to other Canadians, national data indicates that Aboriginals are seven times more likely to be murdered (Moyer, 1992). Urban based studies in Western Canada using police data show violent victimization rates to be three times to five times higher for Native Canadians (Trevethan, 1992). In her self-report study of inner-city Aboriginals, LaPrairie (1994) found that 66 percent of respondents had experienced some type of violent victimization (robbery, sexual assault, assault). This rate is very high, but is partly attributable to the study's high risk population (inner city) and inclusive survey measure of violent victimization, which asked "Have you ever been victimized?" as opposed to the more commonly asked survey item: "Have you been victimized in the last year?"

In summary, the empirical evidence indicates greater violent victimization amongst Canada's Aboriginal peoples, consistent with rates found amongst racial minorities in the United States. For example, Bachman (1992) found much higher rates of homicide among Native Americans than non-Native Americans. Likewise, survey data from the National Criminal Victimization Survey (NCVS) indicates that African-Americans and Hispanic Americans experience higher rates of violence than Whites (BJS, 1997).

If racial minorities experience more violent victimization, then these traumatic experiences should lead to higher fear levels. Disadvantaged minorities 
should be more fearful because they perceive that they are more likely to be victimized. This is related to the causal notion that victimization heightens fear of crime (Dubow, McCabe \& Kaplan, 1979; Garofalo, 1979; Ollenburger, 1981; Skogan \& Maxfield, 1981).

Investigators have found, however, equivocal effects of victimization (violent and otherwise) on fear. Most researchers report weak victimization effects on fear (Skogan, 1987; Weinrath and Gartrell, 1996). Furthermore, some studies have found violent experiences to result in less fear, and that these effects are conditioned by gender (for a recent summary, see Marquez, 1996; see also Weinrath and Gartrell, 1996). Some observers attribute these findings to faulty theory and methodological problems (Ferraro, 1995; Bilsky \& Wetzels, 1997), while other investigators have hypothesized that victimization may lead to coping responses in individuals that lessen fear. For example, victims may employ psychological techniques of neutralization in response to assault, perhaps verbalizing that "it wasn't so bad" (Agnew, 1985). They may actually experience a defensive reaction or "secondary effect" from their victimization experience (Van Der Wurff \& Stringer, 1989). Victimization may result in a learning effect that leads to more prudent, precautionary behaviors by individuals, thereby promoting feelings of personal safety (Skogan, 1987).

The literature points to a number of probable relationships between race and fear of crime. Aboriginals are expected to report higher fear levels than other Canadians, because they lack social resources and are more likely to experience violent victimization. Age and gender may have a multiplicative (interaction) effect on Aboriginals, because the gap between perceptions of vulnerability will increase more for male Aboriginals because of greater income gaps with NonAboriginal males. Before these relationships are examined, we will seek to replicate associations between Aboriginal fear of crime and factors that have been found salient in previous tests of fear of crime vulnerability models. We expect that female and elderly Aboriginals will feel more vulnerable to crime, and express more fear. Those who are not married will be more fearful because they will be more likely to live on their own, lack the reassuring presence of another person, and overestimate the amount of crime that might occur. Aboriginals living in urban settings will perceive more crime and express greater fear, while those existing on limited income will feel more fearful because they will not be in a position to live in lower crime areas or purchase devices to safeguard them, like alarm systems or heavy duty locks.

\section{RESEARCH DESIGN}

\section{Data Sets}

We investigate our research hypotheses on race and fear of crime by way of two national adult (15+ years) surveys conducted by the Canadian federal 
government's Statistics Canada Department. The Aboriginal People's Survey (APS) was conducted in 1991 and combined in-person and telephone interviews to collect data from a sample of 25,122 Aboriginal peoples across Canada. It was a post-censal survey based on the 1990 census and followed up a subsample of individuals who identified themselves as Aboriginal (Statistics Canada, 1993), and is the largest survey ever done involving Canada's Aboriginal peoples. The 1993 Canadian General Social Survey (GSS) contains self-reports from 10,000 Canadians, and is part of an ongoing series of national surveys by Statistics Canada involving issues such as health, crime, victimization, and other social issues. The large samples provided by these surveys are particularly helpful in examining the phenomena of victimization, which is a statistically rare event and hence, difficult to assess even in moderate sized surveys of 500-1,000 cases. Even more importantly, the two studies both utilized fear, victimization, and demographic measures similar enough to each other to allow for useful comparison.

The time period between the two national survey interviews ranged from 13-24 months, a relatively short period. Ideally, these surveys would have been undertaken in the same year. Any differences observed in analysis might be due to subjects having been interviewed in different time periods, when feelings of fear and victimization experiences may have been influenced by political or economic events, or shifts in social attitudes. Yet, there is likely little reason to expect differences due to time effects because Canadian assault rates and fear levels were stable during the early 1990s. National assault rates for 1991, 1992 and 1993 in the Canadian Uniform Crime Reports are quite alike (Gartner and Doob, 1994). Only a meager 2\% difference can be discerned in the reported assault rate from 1991 to 1993 (1991: 805/100,000, 1992: 814/100,000, 1992: 824/100,000). Self-report assault measures are also quite equivalent. The 1987 GSS survey assault rate of 67 per 1,000 is almost identical to the 1993 rate of 68 per 1,000. Reported fear levels are also similar: 25 percent of Canadians reported feeling unsafe in 1987, quite similar to the 27 percent in the 1993 GSS (Gartner \& Doob, 1987). Given this stability in official and self-report assault rates, as well as fear levels, it is unlikely that findings reported here are markedly influenced by the timing of the surveys.

These two data sets present many advantages for analysis. They both provide large samples, include important demographic indicators, and ask similar questions that assess both victimization and fear of crime. In the case of Aboriginal Canadians, the APS represents one of the few opportunities to use a national data set. The Canadian General Social Survey does not capture ethnic identity, and hence does not offer the chance to do a comparison. 


\section{Variables}

A dichotomous dependent variable $(1=$ yes, $0=$ no $)$ is used to assess the dependent variable of fear of crime, using the question "Do you feel unsafe walking in your neighborhood at night?" Demographic variables and assault make up the independent variables we will use to establish fear correlates. Gender is coded as female 1 and male 0 . Age is evaluated using a seven category variable, and social support is assessed by classifying those married/ common-law as 1 , and those living alone (single, divorced) as 0 . Income is categorized by using 5 household earning levels, and location is broken down into Rural $=0$, Reserve or Settlement $=1$, Smaller urban setting $=2$, and Large urban setting $=3$. In the comparison of Aboriginal and Non-Aboriginal fear, location is collapsed further into two categories of rural/urban, because there is no Non-Aboriginal equivalent for Indian Reserve or Métis Settlement. Assault $(1=$ yes, $0=$ no $)$ is indicated by a positive response to the question "Were you assaulted/attacked in the last year?"

This research uses the vulnerability model to examine fear of crime. There is some debate in the literature on the utility of this model, as it is argued that the "walk in neighborhood" question measures risk perception, as opposed to a more salient appreciation of an individual's affective state of crime related fear or anxiety (Ferraro, 1995). In other words, just because a person stays home it may not mean that they worry a great deal about becoming a victim. While it is acknowledged that multiple measures of fear are preferable, it remains that the walk in neighborhood question is a useful indicator because it assesses directly the behavioral impact of fear on individuals, particularly the fear women may hold towards sexual assault. An individual may stay at home because they fear crime, and this in turn reduces their worry. Given these linkages, it is not reasonable to dismiss the walk in neighborhood questions as a valid fear of crime measure.

In the following analysis, a contingency table is first used to examine bivariate relationships between vulnerability and fear of crime for Aboriginal Canadians. Tabular analysis is conducted to compare Aboriginal and NonAboriginal fear of crime patterns. Finally, multivariate logistic regression allows us to rank factors related to fear of crime, and to further compare Aboriginal and Non-Aboriginal fear levels.

About 64 percent of both APS and GSS respondents reported that they were married. There are some demographic differences between the samples that require attention. Using weighted totals, the APS indicates that Aboriginals are more rurally based $(47.1 \%)$ compared to GSS Non-Aboriginals (25.1\%). There are also more females in the Non-Aboriginal sample (45.4\% APS, $50.8 \%$ GSS). Because of a shorter life expectancy for Native Canadians, those over 65 comprise only 4.9 percent of the APS sample, compared to 13.4 percent of the GSS. These distributions suggest that overall reported 
fear levels might favor Aboriginals, because Non-Aboriginals are more urbanly based, female, and elderly. Yet sample attributes do not favor Aboriginals when income differences are considered. Aboriginals (67.8\%) are twice as likely to report income levels below $\$ 9,999$ than Non-Aboriginals (30.5\%). Non-Aboriginals are also much more likely to report income over $\$ 40,000$ (18.9\%) than Native Canadians, who are quite disadvantaged $(4.8 \%)$. While these factors may balance out, use of multivariate regression will also allow us to control for the possible influence of these characteristics.

\section{RESULTS}

\section{Bivariate Relationships for Aboriginals and Fear of Crime}

Aboriginal Canadians generally report feeling safe (Table 1). Twentythree and a half percent $(23.5 \%)$ of respondents expressed fear of crime, which indicates that 76.5 percent felt comfortable walking alone in their neighborhood at night. Aboriginal Canadians expressing greater fear include females, the elderly, those with low income, urban dwellers, and assault victims. Females are 24.8 percent more likely to report fear than males, large city dwellers 17.6 percent more likely than those living in very rural settings,

\begin{tabular}{|c|c|c|c|c|c|}
\hline \multicolumn{6}{|c|}{$\begin{array}{l}\text { Percentage of Respondents Answering "Yes" to: } \\
\text { "Feel Unsafe Walking in Your Area at Night" }\end{array}$} \\
\hline FEAR-ALL RES & PONDENTS & $23.5 \%$ & & & \\
\hline \multirow[t]{2}{*}{ Gender } & Male & $10.3 \%$ & Income & Under $\$ 9,999$ & $26.4 \%$ \\
\hline & Female & $35.1 \%$ & & $\$ 10,000-\$ 19,999$ & $21.5 \%$ \\
\hline \multirow[t]{7}{*}{ Age } & $15-19$ & $19.0 \%$ & & $\$ 20,000-29,999$ & $19.0 \%$ \\
\hline & $20-24$ & $24.1 \%$ & & $\$ 30,000-39,999$ & $17.2 \%$ \\
\hline & $25-29$ & $22.9 \%$ & & $\$ 40,000$ and over & $10.1 \%$ \\
\hline & $30-39$ & $22.6 \%$ & Location & Other rural & $16.0 \%$ \\
\hline & $40-49$ & $23.0 \%$ & Rese & erve or Settlement & $19.1 \%$ \\
\hline & $50-64$ & $27.0 \%$ & & Other urban & $26.4 \%$ \\
\hline & $65+$ & $36.2 \%$ & & Large city & $33.6 \%$ \\
\hline \multirow[t]{2}{*}{ Marital Status } & Married/Common-Law & $22.9 \%$ & Violent Victimization & Yes & $26.6 \%$ \\
\hline & Single/Divorced/Widowed & $23.9 \%$ & & No & $23.1 \%$ \\
\hline
\end{tabular}


the elderly (65+) show 17.2 percent higher fear levels compared to those 19 years and younger, while those with household earnings under $\$ 9,999$ are $16.4 \%$ more likely to report fear than those earning over $\$ 40,000$. Violent victimization increased reported fear only a modest 3.5 percent. The hypothesized association between social support (marital status) is not supported, as only a 1 percent difference in fear levels is observable between those married and those not. Fear relationships are not always linear. In the case of income, the largest difference appears to occur after a $\$ 40,000$ threshold is reached. Likewise with age, fear increases most substantially after age 65 .

While weak or negligible effects were observed for victimization and marital status, other findings were consistent with past vulnerability model research.

\section{Comparison with Non-Aboriginal Population}

Reported assaults are twice as high for Aboriginals (7.6\%) as Non-Aboriginals $(3.2 \%)$, which is similar to the pattern reported in other studies. Despite greater victimization racial differences in fear of crime are small (Table 2). Aboriginals reporting fear total 23.5 percent, in contrast to a slightly higher 26.4 percent of Non-Aboriginals. In addition to other factors discussed earlier, this difference may be largely due to the rural living pattern of Aboriginal Canadians. About 30 percent of both urban based Aboriginals and Non-Aboriginals report being afraid of walking in their neighborhood at night. Even in urban settings, however, Aboriginals are not more likely to express fear.

Findings for both groups are generally consistent with the vulnerability model. Interestingly, female Aboriginals are 8 percent less likely to express fear than Non-Aboriginal women. Race and age do not appear to make a difference until the age of 65 , when Non-Aboriginals report fear levels that are $7.6 \%$ higher than Aboriginals. Contrary to the shift in fear observed amongst African-Americans, older Aboriginals are less afraid than older Non-Aboriginals. Lower income is also associated with greater fear levels for Non-Aboriginals. In the groups earning $\$ 29,999$ or lower, Non-Aboriginals are 6-9 percent more fearful than Aboriginal Canadians. The fear gap shrinks to about 3 percent between higher income racial groups, with high income Non-Aboriginals again more afraid.

Marital status shows a stronger (albeit small) association with fear for NonAboriginals, a difference of about 4 percent, compared to only 1 percent for Aboriginals. Racial differences in victimization effects on fear are small (1\%).

\section{Multivariate Analysis of Fear}

Despite higher rates of reported victimization and lower income, Aboriginals express lower fear levels than Non-Aboriginals. This finding is unex- 


\section{Table 2: Comparison of Fear of Crime (Safe Walking in Your Area at Night?) Between Aboriginal and Non-Aboriginal Population by Gender, Age, Marital Status, Income, Urban/Rural Location, and Violent Victimization}

\begin{tabular}{|c|c|c|c|c|c|c|c|}
\hline \multicolumn{8}{|c|}{$\begin{array}{l}\text { Percentage of Respondents Answering "Yes" to: } \\
\text { "Feel Unsafe Walking in Your Area at Night" }\end{array}$} \\
\hline & & Abor. & $\begin{array}{l}\text { Non- } \\
\text { Abo }\end{array}$ & & & Abor. & $\begin{array}{l}\text { Non- } \\
\text { Abo }\end{array}$ \\
\hline FEAR-ALL RESPONDENTS & TS Yes & $23.5 \%$ & $26.4 \%$ & $\begin{array}{r}\text { Mar } \\
\text { Married/Co }\end{array}$ & $\begin{array}{l}\text { Status } \\
\text { on-Law }\end{array}$ & $22.9 \%$ & $25.1 \%$ \\
\hline \multirow[t]{2}{*}{ Gender } & Male & $10.3 \%$ & $10.2 \%$ & Single/Divorce & idowed & $23.9 \%$ & $29.1 \%$ \\
\hline & Female & $35.1 \%$ & $43.1 \%$ & & & & \\
\hline \multirow[t]{9}{*}{ Age } & $15-19$ & $19.0 \%$ & $22.2 \%$ & Income Ur & $\$ 9,999$ & $26.4 \%$ & $32.6 \%$ \\
\hline & $20-24$ & $24.1 \%$ & $24.0 \%$ & $\$ 10,0$ & $\$ 19,999$ & $21.5 \%$ & $30.1 \%$ \\
\hline & $25-29$ & $22.9 \%$ & $25.5 \%$ & $\$ 20$, & $-29,999$ & $19.0 \%$ & $25.3 \%$ \\
\hline & $30-39$ & $22.6 \%$ & $22.5 \%$ & $\$ 30$, & $-39,999$ & $17.2 \%$ & $20.6 \%$ \\
\hline & $40-49$ & $23.0 \%$ & $23.6 \%$ & $\$ 40,0 c$ & nd over & $10.1 \%$ & $12.5 \%$ \\
\hline & $50-64$ & $27.0 \%$ & $28.0 \%$ & Location & Rural & $18.0 \%$ & $17.1 \%$ \\
\hline & $65+$ & $36.2 \%$ & $43.8 \%$ & & Urban & $29.7 \%$ & $30.3 \%$ \\
\hline & & & & Violent Vic & ization & & \\
\hline & & & & & Yes & $26.6 \%$ & $27.6 \%$ \\
\hline
\end{tabular}

Source: Aboriginal People's Survey, 1991; Canadian General Social Survey, 1993

pected, but may not hold in controlled analysis. Because of the much larger proportion of Aboriginals residing on Indian Reserves, Métis Settlements, or other rural locations, the following logistic regression will focus on both urban based Aboriginals and Non-Aboriginals. Indeed, given the sometimes questionable applicability of the "walk in neighborhood" measure to rural settings, an urban based analysis may be more valid in any event. The large samples make almost all findings statistically significant, hence direction and magnitude of effect will be emphasized in the reported findings that follow.

To simplify interpretation, age and income variables are recoded into four dichotomous measures. Those aged 15-19 are classified as "young," 65 and older are "elderly," with those 20-64 comprising the comparison group. Those earning $\$ 9,999$ or less are "low income," those earning $\$ 40,000$ or more were "higher income," while those reporting household incomes of $\$ 10,000-39,999$ were the reference group. The decision to use income as a socioeconomic status measure resulted in a loss of $15.1 \%$ APS cases and $17.7 \%$ of GSS cases. Logistic regressions were run without income, and gender, age, marital status and assault effects were remarkably similar. Con- 
V Table 3: Logistic Regression of Fear of Crime on Gender, Age, Marital Status, Income, Location, and Violent Victimization (Assault)

\begin{tabular}{|c|c|c|c|c|}
\hline Variables & Aboriginals & $\begin{array}{c}\text { Non- } \\
\text { Aboriginals }\end{array}$ & Aboriginals & $\begin{array}{c}\text { Non- } \\
\text { Aboriginals }\end{array}$ \\
\hline & B & B & $\operatorname{Exp}(b)$ & $\operatorname{Exp}(b)$ \\
\hline $\begin{array}{r}\text { Gender } \\
(\text { Female }=1 \text { Male }=0)\end{array}$ & $\begin{array}{l}1.713 \\
(.014)\end{array}$ & $\begin{array}{l}1.871 \\
(.002)\end{array}$ & 5.546 & 6.493 \\
\hline $\begin{array}{r}\left.\begin{array}{r}\text { Young } \\
(15-19 \text { years }=1, \text { else } 0)\end{array}\right)\end{array}$ & $\begin{array}{r}0.433 \\
(.019)\end{array}$ & $\begin{array}{r}.394 \\
(.003)\end{array}$ & 649 & .674 \\
\hline $\begin{array}{r}\text { Elderly } \\
(65+=1, \text { else } 0)\end{array}$ & $\begin{array}{r}.749 \\
(.030)\end{array}$ & $\begin{array}{r}1.0293 \\
(.002)\end{array}$ & 2.115 & 2.799 \\
\hline $\begin{array}{r}\text { Married/Common-Law } \\
(1=\text { Yes, } 0=\text { No })\end{array}$ & $\begin{array}{r}0.017 \\
(.013)\end{array}$ & $\begin{array}{r}0.065 \\
(.015)\end{array}$ & .984 & .938 \\
\hline $\begin{array}{r}\text { Low Income } \\
(1=\text { Under } \$ 9,999 \text {, else } 0)\end{array}$ & $\begin{array}{r}.280 \\
(.014)\end{array}$ & $\begin{array}{r}.235 \\
(.016)\end{array}$ & 1.323 & 1.265 \\
\hline $\begin{array}{r}\text { Higher Income } \\
(\$ 40,000 \text { and over }=1 \text {, else })\end{array}$ & $\begin{array}{l}0.394 \\
(.035)\end{array}$ & $\begin{array}{l}0.473 \\
(.002)\end{array}$ & .675 & .623 \\
\hline $\begin{array}{r}\text { Assaulted in past year } \\
(1=\text { yes, } 0=\text { no })\end{array}$ & $\begin{array}{r}.344 \\
(.022)\end{array}$ & $\begin{array}{r}.251 \\
(.037)\end{array}$ & 1.411 & 1.296 \\
\hline Constant & 2.155 & 2.113 & & \\
\hline $\begin{array}{r}N \\
\text { Missing }\end{array}$ & $\begin{array}{l}7037 \\
1255\end{array}$ & $\begin{array}{l}6000 \\
1291\end{array}$ & & \\
\hline
\end{tabular}

sequently, missing cases are not felt to limit the validity of the findings reported here, and income was included in the logistic regression equations.

In the urban logistic regression, most relationships observed in the bivariate table are still present, and effects are in the predicted direction. Gender and age are associated with higher fear levels for Non-Aboriginals. Aboriginal females are more likely to be fearful than Native males by a factor of 5.6, making them appear slightly less afraid than Non-Aboriginal females, who are 6.5 times as likely to report fear as males. Younger Aboriginals and Non-Aboriginals are both about 1.5 times less likely to be fearful than those in the middle age group. Elderly Non-Aboriginals reported fear levels are 2.8 times as high as the middle age group, greater than the factor of 2.2 distinguishing elderly Aboriginals. Marital status has only a negligible effect on fear.

Low income and assault have slightly more negative consequences for Aboriginals in the logistic regression. Victimized Aboriginals report greater fear levels by a factor of 1.4, compared to 1.3 for Non-Aboriginals. Caution should be exercised in interpreting these findings because the magnitude of effect for racial differences is small. Low income Aboriginals (1.32) are slightly more likely to report fear than low income Non-Aboriginals (1.27). 
Natives earning more than $\$ 40,000$ are 1.5 times less likely to report fear than middle income Aboriginals, almost identical to higher earning Non-Aboriginals, who are 1.6 times less likely to be afraid than those earning less. Whether or not one is Aboriginal or Non-Aboriginal, having more money means you will be less fearful.

\section{DISCUSSION}

Most hypotheses concerning Aboriginal Canadians and fear of crime correlates were supported. Consistent with other research, females and the elderly were much more likely to report fear. Low income increased the likelihood of fear, while those earning more than $\$ 40,000$ per year were less afraid. Marital status only marginally reduced the likelihood of fear for Aboriginals. Living in increasingly urban settings was associated with greater fear. Overall findings indicate that gender and age exert the largest effects on fear, while marital status and assault exert only small effects. Socioeconomic status has a moderate effect. The use of secondary survey data resulted in large samples with good external validity, but better measures of social support, victimization and socioeconomic status may have resulted in more notable effects.

Race did not appear to have much of a relationship with fear of crime. Aboriginals were not more afraid than Non-Aboriginals. The multiple jeopardy hypothesis that race would interact with age and gender to produce greater differences in fear was not supported. In fact, female and elderly Non-Aboriginals in similar circumstances were often more afraid. Personal experience with violence did not appear to have a substantial impact on either Aboriginals or Non-Aboriginals. APS respondents reported twice as much violence as Non-Aboriginals, and the extant research indicates that Native Canadians experience higher rates of more lethal forms of violence such as homicide, but fear levels do not appear to be affected. While some American studies have attributed the lack of race effect differences to White fear of African-Americans (Chiricos, Hogan \& Gertz, 1997), this explanation is more difficult to apply to Aboriginal Canadians. African Americans make up about 12 percent of the US population, while Aboriginal Canadians make up only 5 percent of Canada's population, and live more in rural settings, on homogenous Indian Reserves or Métis Settlements. A more plausible explanation is that Aboriginal Canadians' fear is conditioned by their onerous life circumstances. Given their limited access to social resources, and the frequency with which they must face adversity, Aboriginals have many other things to worry about besides crime.

In this analysis income findings are the most disconcerting. In controlled analysis having less money did have slightly greater effects on Aboriginals, and we know that a greater proportion of them are low income. On the other 
hand, those who report higher income are less afraid, again with Aboriginals less likely to see over $\$ 40,000$ a year in household income. Clearly, urban based, poor Aboriginals remain a priority for policy makers. Until greater social equality is achieved, this group will experience more fear.

On a more positive note, the rurally based living circumstances of many Aboriginals were associated with less fear. Lower crime rates and the extensive kinship and community networks that exist on many Indian Reserves and Métis Settlements appear to help people feel less afraid.

Future research can be undertaken at the community level to further our understanding of Aboriginal and Non-Aboriginal differences in fear of crime, both in urban and rural settings. Multiple measures of fear, using culturally sensitive definitions, would improve our ability to measure fear. Qualitative designs could provide insight into the social experience of crime and help to guide the design of better fear instruments. Rather than crime suppression initiatives such as more police or greater use of citizen patrol volunteers, policy makers should emphasize programs that build on existing kinship networks among urban based Aboriginals who live in low income situations. Building on Aboriginal strengths holds more promise than simply increasing coercive measures of social control.

\section{REFERENCES}

Agnew, R.S. (1985). Neutralising The Impact of Crime. Criminal Justice and Behaviour, 12, 221-239.

Bachman R. (1992). Death and Violence on the Reservation: Homicide, Family Violence and Suicide in American Indian Populations. New York: Auburn House.

Bilksy, W., \& Wetzels, P. (1997). On the relationship between criminal victimization and fear of crime. Psychology, Crime \& Law, 3, 309-318.

Box, S., Hale,C., \& Andrews G. (1988). Explaining Fear of Crime. British Journal of Criminology, 28, 340-356.

Bureau of Justice Statistics, National Crime Victimization Survey. (1997). Criminal Victimization 1996. Washington: US Department of Justice.

Chiricos, T., Hogan, M. \& Gertz M. (1997). Racial Composition and Fear of Crime. Criminology, 35, 107-131.

Dubow, F., McCabe, E., \& Kaplan G. (1979). Reactions to Crime: A Critical Review of the Literature. Washington, D.C.: National Institute of Justice, U.S. Department of Justice.

Ferraro, K.F. (1995). Fear of Crime: Interpreting Victimization Risk. Albany: SUNY Press.

Garofalo, J. (1979). Victimization and the Fear of Crime. Journal of Research in Crime and Delinquency, 16, 80-97.

Gartner, R. \& Doob, A. (1994). Trends in Criminal Victimization: 1988-1993. Juristat. Centre for Justice Statistics. Ottawa. 
Keane, C. (1992). Fear of crime in Canada: an examination of concrete and formless fear of victimization. Canadian Journal of Criminology, 34, 215-224.

Long, D. (1996). On violence and healing: aboriginal experiences. In J.I. Ross (Ed), Violence in Canada: Sociopolitical Perspectives. (pp. 40-77). Toronto: Oxford University Press.

LaPrairie, C. (1994). Seen But Not Heard: Native People in The Inner City. Ottawa: Department of Justice. Cat. No. J2-132/1995/E.

May, Moyer, S. (1992). Race, gender and homicide: comparisons between Aboriginals and other Canadians. Canadian Journal of Criminology 3, 387-402.

Marquez, S. (1996). Fear of crime: some evidence of an inverse relationship. Paper presented at the annual meetings of the Pacific Sociological Meetings, Seattle, Washington.

Ollenburger, J.C. (1981). Criminal victimization and fear of crime. Research on Aging, 3, 101-118.

Ortega, S.T. and Myles J.L. (1987). Race and gender effects on fear of crime: an interactive model with age. Criminology, 25, 133-152.

Parker, K., \& Ray C.R. (1990). Fear of crime: an assessment of related factors. Sociological Spectrum, 10, 29-40.

Roberts J. \& Doob, A. (1997). Race, ethnicity and criminal justice in Canada. Crime and Justice: A Review of Research, 469-522.

Skogan, W.G. (1987). The impact of victimization on fear. Crime and Delinquency, 33,135-154.

Skogan, W.G. and Maxfield, M. (1981). Coping With Crime. Beverly Hills: Sage.

Statistics Canada. (1991). Aboriginal people's survey: language, tradition, health, lifestyle and social issues. Ottawa: Minister of Industry, Science and Technology. Cat. No. 89-533. . (1993). Aboriginal People's Survey User's Guide. Ottawa: Ontario. . (1994). The General Social Survey 1993 Personal Risk. Ottawa: Ontario . (1995). Canadian crime statistics. Juristat. Ottawa: Canadian Centre for Justice Statistics.

Trevethan, S. (1992). Police Reported Aboriginal Crime in Calgary, Regina and Saskatoon. Ottawa: Canadian Centre for Justice Statistics.

Van Der Wurff, A. \& Stringer, P. (1989). Postvictimization fear of crime. Journal of Interpersonal Violence, 4, 469-481.

van Diijk, J., \& Mayhew, P. (1997). Criminal Vicitmisation in Eleven Industrialized Countries: Key Findings of the 1996 International Crime Victims Survey.

Weinrath, M. (1998). Victimization and aboriginal Canadians. Paper presented at the annual meetings of the Academy of Criminal Justice Sciences. Albuquerque, New Mexico.

Weinrath, M. and Gartrell J. (1996). Victimization and fear of crime. Violence and Victims, 11, 187-197. 
120 Race, Ethnicity, Sexual Orientation, Violent Crime: The Realities and the Myths

\section{AUTHOR'S NOTES}

Michael Weinrath is an assistant professor jointly appointed in the Department of Sociology and the Justice \& Law Program at the University of Winnipeg. His current research projects involve drunk driver risk assessment, a national study on prison climate effects on inmate recidivism, and prison gangs. His recent publications have appeared in Crime and Delinquency and Violence and Victims.

Address correspondence to Michael Weinrath, PhD, Department of Sociology, University of Winnipeg, 515 Portage Avenue, Winnipeg, Manitoba, R3B, 2E9 Canada. 